\title{
Comparison of Two PCR Assays for Trichomonas vaginalis
}

\author{
Chang-Suk Noh ${ }^{1, \dagger}$, Sang-Su Kim²,3,†, Sung-Yul Park, Hong-Sang Moon ${ }^{4}$, Yeonchul Hong ${ }^{5}$, Jae-Sook Ryu²,3,* \\ 'Department of Internal Medicine, Hallym University Hangang Sacred Heart Hospital, Seoul 07247, Korea; ${ }^{2}$ Department of Environmental Biology \\ and Medical Parasitology; ${ }^{3}$ Department of Biomedical Science, Hanyang University Graduate School of Biomedical Science and Engineering; \\ ${ }^{4}$ Department of Urology, Hanyang University College of Medicine, Seoul 04763, Korea; ${ }^{5}$ Department of Parasitology and Tropical Medicine, \\ Kyungpook National University School of Medicine, Daegu 41944, Korea
}

\begin{abstract}
PCR is known to be the most sensitive method for diagnosing Trichomonas vaginalis infections. This study aimed to compare the sensitivity of a PCR assay for trichomoniasis (HY-PCR) developed in Hanyang University with the use of a Seeplex Ace Detection $\mathrm{Kit}^{\circledR}$, using urine collected from four Korean men with prostatic disease. Overall, HY-PCR was more sensitive than the Seeplex Kit. The use of Chelex 100 is recommended for DNA isolation in order to increase the sensitivity of the PCR test.
\end{abstract}

Key words: Trichomonas vaginalis, PCR, DNA isolation

Trichomonas vaginalis infection is the most prevalent non-viral sexually transmitted infection worldwide. The World Health Organization (WHO) estimated that 248 million people were infected with T. vaginalis in 2005, and by 2008 this number had increased by $11.8 \%$ to 276.4 million [1]. According to recent studies, women infected with $T$. vaginalis are at high risk of vaginitis, endometritis, atypical pelvic inflammatory disease, and adverse pregnancy outcomes [2,3]. In men T. vaginalis increases the risk of infertility and prostate cancer [4]. Moreover, T. vaginalis infection has been linked with increased risk and transmission of HIV [5-7]. Given the clinical significance of T. vaginalis infection, accurate diagnosis is required.

Various methods have been used to diagnose trichomoniasis, such as wet mount and culture. Wet mount examination is straightforward and rapid, but more than $10^{3} / \mathrm{ml}$ live protozoa are needed, and culture requires inocula of 300-500 trichomonads/ml and a specialized medium, as well as taking 2-5 days [8]. Because of these limitations, a highly sensitive and specific PCR method has been used in recent years $[9,10]$. In fact, multiplex PCR assays have been used extensively to diagnose sexually transmitted infections (STIs), because they allow for faster detection, and reduce labor and reagent costs $[11,12]$. The Seeplex_

- Received 19 November 2018, revised 23 January 2019, accepted 31 January 2019.

*Corresponding author (jsryu@hanyang.ac.kr)

${ }^{\dagger}$ These authors contributed equally to this work.

(c) 2019, Korean Society for Parasitology and Tropical Medicine

This is an Open Access article distributed under the terms of the Creative Commons Attribution Non-Commercial License (http://creativecommons.org/licenses/by-nc/4.0) which permits unrestricted non-commercial use, distribution, and reproduction in any medium, provided the original work is properly cited.
STD6 auto-capillary electrophoresis (ACE) detection assay employs 6 pairs of dual priming oligonucleotide $\left(\mathrm{DPO}^{\mathrm{TM}}\right)$ primers specifically targeting unique genes of Chlamydia trachomatis, Neisseria gonorrhoeae, Mycoplasma genitalium, Ureaplasma urealyticum, Mycoplasma hominis, and Trichomonas vaginalis [12].

The present study aimed to compare the sensitivity for detecting T. vaginalis infections of the Seeplex ${ }^{\circledR}$ ACE Detection Kit (Seegene, Seoul, Korea) with that of a PCR assay, HY-PCR, developed in our laboratory.

A total of 4 urine samples were used, 2 from BPH patients and 2 from prostate cancer patients. The 4 Korean patients were being treated in the Department of Urology, Hanyang University Hospital. The study was approved by the Institutional Review Board of Hanyang University, and written informed consent was obtained from the patients and controls (IRB No. HYUH 2013-04-028-006).

First-voided urine (VB1) specimens were used in the PCR assays [10]. The VB1 samples (30-40 ml) from the 4 patients were provided in sterile $50 \mathrm{ml}$ screw-cap plastic tubes, immediately frozen at $-20^{\circ} \mathrm{C}$, and transported on ice to the laboratory where they were thawed and centrifuged for $10 \mathrm{~min}$ at 1,500 g. The supernatants were aspirated, and the sediments were transferred to tubes containing $3 \mathrm{ml}$ PBS.

DNA was prepared by 2 methods; following the instructions with the QIAamp ${ }^{\circledR}$ DNA Mini Kit (Qiagen, Valencia, California, USA), and heat-treating with a chelating resin (Chelex) [13]. The manufacturer's instructions for the QIAamp ${ }^{\circledR}$ DNA Mini Kit were as follows; $200 \mu \mathrm{l}$ washed urine sample was 
mixed with $20 \mu \mathrm{l}$ Protease K, and $200 \mu \mathrm{l}$ Buffer AL was added to $200 \mu \mathrm{l}$ of sample and incubated at $56^{\circ} \mathrm{C}$ for $10 \mathrm{~min} .200 \mu \mathrm{l}$ ethanol was added and the mixture was applied to a QIAamp ${ }^{\circledR}$ Mini spin column (in a $2 \mathrm{ml}$ collection tube) and centrifuged at 6,000 $\mathrm{g}$ for $1 \mathrm{~min}$ and the tube containing the filtrate was discarded. $500 \mu \mathrm{l}$ Buffer AW1 was added to the Mini spin column and centrifuged at 6,000 $\mathrm{g}$ for $1 \mathrm{~min}$, and the tube containing the filtrate again discarded. The Mini spin column was placed in a clean $2 \mathrm{ml}$ collection tube, and $500 \mu \mathrm{l}$ Buffer AW2 was added and the column was centrifuged at full speed $(20,000 \mathrm{~g})$ for $3 \mathrm{~min}$, and the tube discarded. $200 \mu \mathrm{l}$ Buffer AE was added to the Mini spin column and centrifuged at $6,000 \mathrm{~g}$ for $1 \mathrm{~min}$. Five $\mu \mathrm{l}$ of Buffer AE containing the eluted DNA was used as DNA template. Thus, the process for isolating DNA with the QIAamp kit involves several steps.

PCR reaction mixtures for the Seeplex ${ }^{\circledR}$ ACE Detection Kit assays contained $5 \times$ STD6 ACE PM (primer) $4 \mu \mathrm{l}$, 8-MOP solution $2.5 \mu \mathrm{l}, 2 \times$ multiplex master mix $10 \mu \mathrm{l}$, STD IC $1 \mu \mathrm{l}$, template $3 \mu \mathrm{l}$. The DNA was initial denatured for $15 \mathrm{~min}$ at $94^{\circ} \mathrm{C}$, followed by 40 cycles of $30 \mathrm{sec}$ denaturation at $94^{\circ} \mathrm{C}, 1 \mathrm{~min} 30$ sec annealing at $63^{\circ} \mathrm{C}$, and $1 \mathrm{~min} 30 \mathrm{sec}$ extension at $72^{\circ} \mathrm{C}$.

DNA for the HY-PCR was prepared by heat-treating with a chelating resin (Chelex) [13]; $1 \mathrm{ml}$ of suspended urine precipitate was centrifuged at 10,000 g for $5 \mathrm{~min}$, resuspended in 200 $\mu \mathrm{l}$ of a $5 \%$ suspension of chelating resin $\left(\right.$ Chelex $^{\circledR} 100$; Sigma, St. Louis, Missouri, USA) in $0.01 \mathrm{M}$ Tris buffer (pH 8.0), and incubated at $56^{\circ} \mathrm{C}$ for $30 \mathrm{~min}$. The preparation was mixed gently, boiled for $10 \mathrm{~min}$, and centrifuged at $12,000 \mathrm{~g}$ for $5 \mathrm{~min}$ in a microcentrifuge, and $5 \mu \mathrm{l}$ of supernatant was used directly as the template for PCR. The primers were based on the T. vaginalis-specific repetitive DNA sequence in clone TV-E650-1 [14].

The primers used were: $5^{\prime}$ gagttagggtctaatgttgatgtg $3^{\prime}$ and $5^{\prime}$ agaatgtgatagcgaaatggg $3^{\prime}$. The PCR reaction mixtures contained $1 \mu \mathrm{l}$ each of the primers at $10 \mathrm{pmol} / \mu \mathrm{l}$ each, $2 \mu \mathrm{l}$ dNTPs (2.5 mM each), $0.1 \mu$ Taq polymerase ( $5 \mathrm{U} / \mu \mathrm{l}), 5 \mu \mathrm{DNA}, 2 \mu \mathrm{l}$ $10 \times$ PCR buffer, $5.2 \mu \mathrm{l} 5 \mathrm{M}$ betaine, and $3.7 \mu \mathrm{l}$ distilled water. The DNA was denatured for $5 \mathrm{~min}$ at $94^{\circ} \mathrm{C}$, followed by $40 \mathrm{cy}$ cles of $10 \mathrm{sec}$ denaturation at $98^{\circ} \mathrm{C}, 30 \mathrm{sec}$ annealing at $55^{\circ} \mathrm{C} /$ $52^{\circ} \mathrm{C}$, and 30 sec extension at $72^{\circ} \mathrm{C}$.

To avoid product carryover, the PCR reactions were set up in an area physically separated from all activities involving amplified target sequences, thermocycling, and running of gels. To assess the sensitivity of the PCR, a suspension of T. vaginalis was counted with a hemocytometer and numbers of tropho-

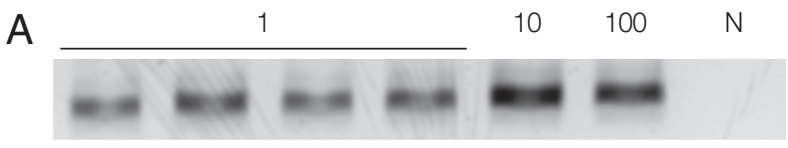

B

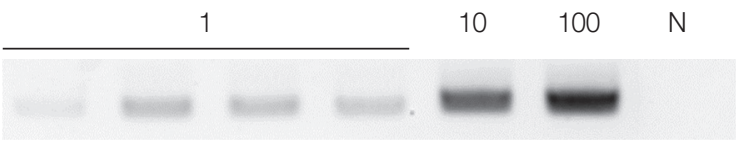

Fig. 1. Sensitivity of HY-PCR tested with varying numbers of trophozoites $(1,10,100)$ of $T$. vaginalis. (A) Chelex ${ }^{\circledR} 100$, (B) QIAamp ${ }^{\circledR}$ DNA Mini Kit were used for DNA extraction. The PCR product formed a 318 bp band. N, Negative control (DW); 1, 10, 100, number of trichomonads used.

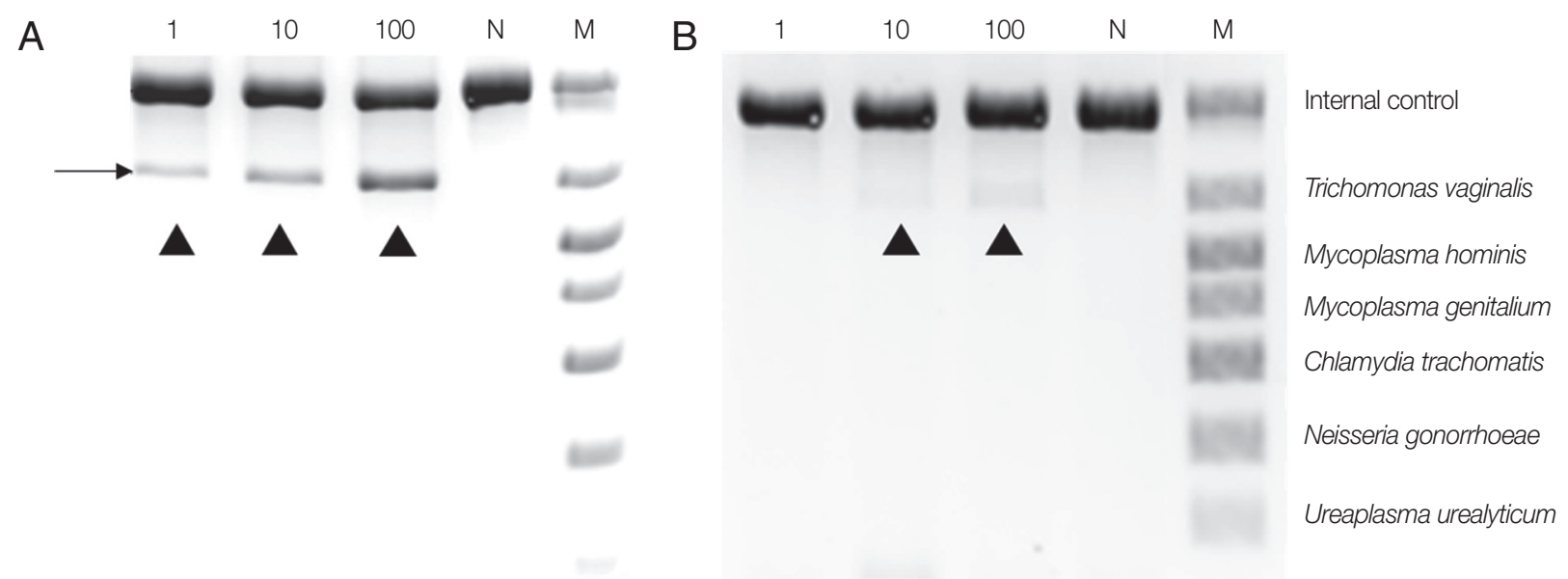

Fig. 2. Comparison between Chelex ${ }^{\circledR} 100(A)$ and QIAamp ${ }^{\circledR}$ DNA Mini Kit (B) as DNA extraction methods for PCR using a Seeplex ${ }^{\circledR}$ ACE Detection Kit. T. vaginalis trophozoites $(1,10,100)$ were added to the urine of a normal male and incubated overnight before DNA extraction. N, negative control (DW); M, marker; arrowhead, T. vaginalis product. 
zoites were adjusted with PBS to 1, 10, and 100 per PCR mixture. To confirm whether or not the 318 bp band obtained by PCR originated from T. vaginalis, nested PCR was undertaken using primers: 5'ATCCCC-AACAATGAACGAAG 3' and 5'AATGTGATAGCGAA-ATGGGA 3'; this confirmed the 181 bp band.

When the HY-PCR assay was performed with DNA extracted with Chelex ${ }^{\circledR} 100$ and with the QIAamp ${ }^{\circledR}$ Mini Kit, the HYPCR assay with DNA extracted by either method gave a positive result with samples containing 1 trophozoite although the latter DNA gave a weaker band than the former (Fig. 1). This result suggests that Chelex ${ }^{\circledR} 100$ is more effective at extracting DNA than the QIAamp ${ }^{\circledR}$ Mini Kit.

To make the conditions similar to those in samples from patients, T. vaginalis trophozoites $(1,10,100)$ were added to the urine of a normal man and incubated overnight, and DNA was extracted with Chelex ${ }^{\circledR}$ 100, or a QIAamp DNA Kit, and PCR was performed with a Seeplex ${ }^{\circledR}$ ACE Detection Kit. DNA from the Chelex ${ }^{\circledR} 100$ gave a positive finding from samples containing 1 trophozoite. In contrast, the DNA exacted with the QIAamp ${ }^{\circledR}$ Mini kit gave only the faintest positive band from 10 trophozoite samples, and 100 T. vaginalis samples yielded dimly visible band (Fig. 2). Therefore, the sensitivity of the Seeplex ${ }^{\circledR}$ ACE Detection Kit PCR seemed to vary depending on how DNA was extracted, and Chelex ${ }^{\circledR} 100$ was again superior to the QIAamp ${ }^{\circledR}$ Mini Kit for extracting DNA.

Next, DNA extracted from the four patient samples was used in the two PCR systems. HY-PCR gave positive findings with all 4 urine samples when using the Chelex ${ }^{\circledR} 100$ (Fig. 3A). By contrast, Seeplex ${ }^{\circledR}$ PCR gave positive findings with only one of the four samples using the Chelex ${ }^{\circledR 100}$ (and none with the DNA made with the QIAamp ${ }^{\circledR}$ Mini Kit) (Fig. 3B, C). In other words, only negative results were obtained in Seeplex ${ }^{\circledR}$ PCR with DNA made with the QiAamp Kit recommended by the Seeplex PCR Kit. Evidently HY-PCR using DNA extracted with Chelex is highly sensitive not only when using cultured trichomonads but also when using patient samples.

However, Seo et al. [15] reported the lower limit of PCR system developed in Kyungpook National University using Tvk3/7 and BTUB9/2 primer set was 1 organism per reaction. When the prevalence of Tv in 201 men attending a Primary Care Urology Clinic was tested with this PCR system, eight men (4\%, 8/201) yielded positive bands. In contrast, all eight gave negative results with the Seeplex ${ }^{\circledR}$ Kit PCR with DNA made with the QiAamp Kit. These findings are consistent with our results.

A
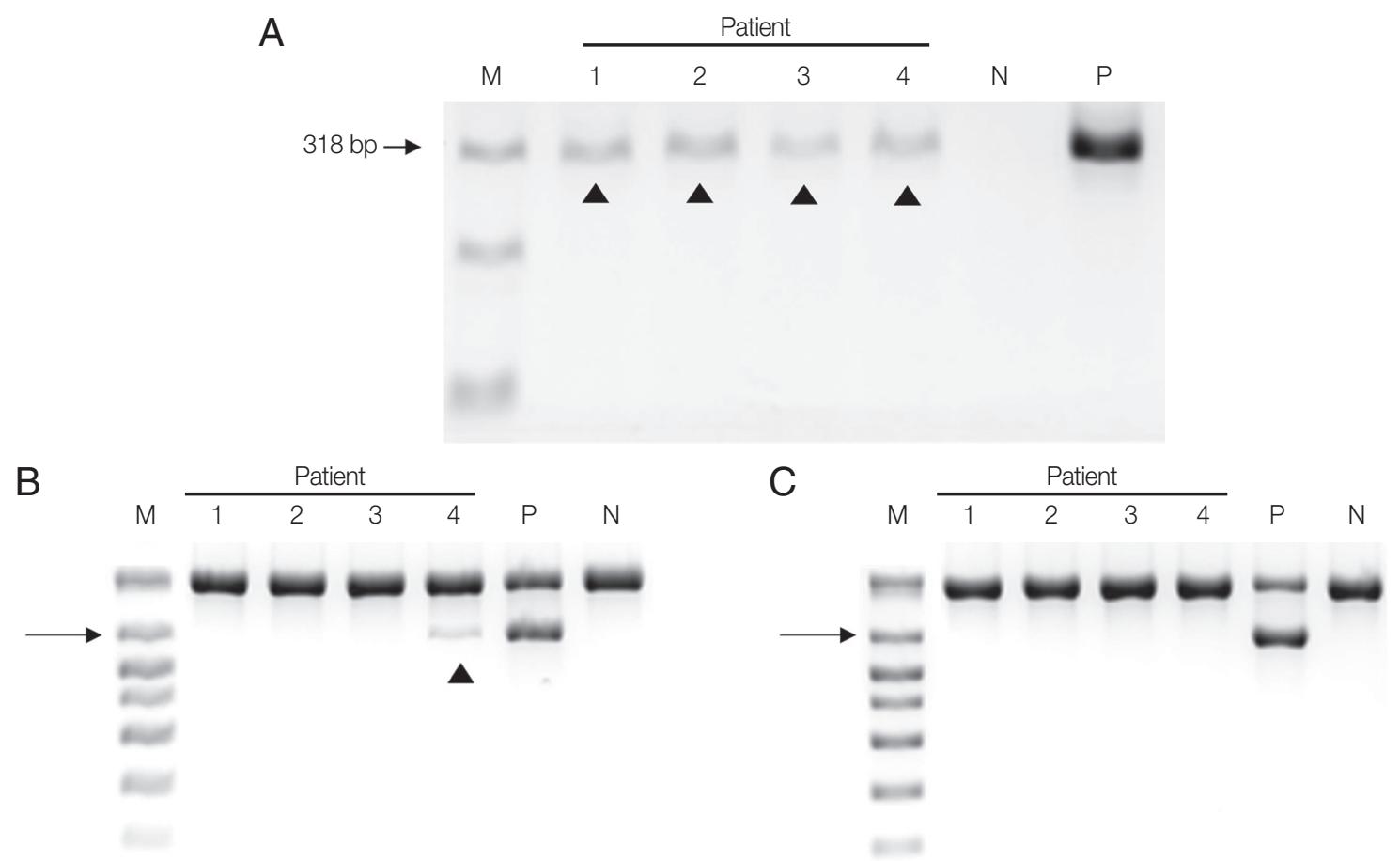

Fig. 3. Two PCR assay systems were used with DNA isolated from the urine of the 4 patients by 2 DNA extraction methods. (A) All 4 urine samples gave positive bands in HY-PCR using DNA extracted with Chelex ${ }^{\circledR} 100$. (B, C) PCR with Seeplex ${ }^{\circledR}$ ACE Detection Kit. (B) Only one of the 4 samples gave a positive band with DNA isolated with Chelex ${ }^{\circledR} 100$, and (C) none gave positive band with DNA extracted with QIAamp ${ }^{\circledR}$ DNA Mini Kit. Arrowhead, T. vaginalis. 
Lee et al. [12] have discussed the possible limitations of multiplex PCR, which include PCR drift due to stochastic fluctuations in the interactions between PCR reagents and competitive inhibition by PCR selection. Despite this limitation, the Seeplex ${ }^{\circledR}$ Kit PCR assay is widely used in clinical practice because it can detect six different pathogens causing sexual transmitted infections at the same time and is cost effective. This multiplex PCR kit was found to be highly sensitive for detecting T. vaginalis because a distinct positive band was observed from a single trophozoites when DNA was isolated by the Chelex method. All our results show that the DNA extraction method influences the sensitivity of the Seeplex PCR system. Interestingly, the QIAamp ${ }^{\circledR}$ Mini Kit did not perform better than Chelex ${ }^{\circledR} 100$ despite its higher cost. The QIAamp ${ }^{\circledR}$ Kit was also one of the more labor-intensive methods tested in the current study, as it included three different incubation temperatures and eight centrifugation steps [16]. Considering that the Seeplex ${ }^{\circledR}$ ACE Detection Kit is used in most of Korean hospitals, the DNA extraction method recommended by the kit should be modified to increase its sensitivity for detecting $T$. vaginalis.

A limitation of this study is that it involved a small number of patient samples. The examination of more samples is needed to ensure confidence in its findings.

In conclusion, considering its clinical importance, there is an urgent need to develop a highly sensitive diagnostic method for T. vaginalis. The present findings should help in this direction.

\section{ACKNOWLEDGMENT}

This research was supported by the Basic Science Program through the National Research Foundation of Korea (NRF) funded by the Ministry of Science and ICT (NRF-2017R1A2B 4002072).

\section{CONFLICT OF INTEREST}

We have no conflict of interest related with this study.

\section{REFERENCES}

1. Bouchemal K, Bories C, Loiseau PM. Strategies for prevention and treatment of Trichomonas vaginalis infections. Clin Microbiol Rev 2017; 30: 811-825.
2. Fichorova RN. Impact of T. vaginalis infection on innate immune responses and reproductive outcome. J Reprod Immunol 2009; 83: 185-189.

3. Moodley D, Sartorius B, Madurai S, Chetty V, Maman S. Pregnancy outcomes in association with STDs including genital HSV2 shedding in a South African cohort study. Sex Transm Infect 2017; 93: 460-466.

4. Mercer F, Johnson PJ. Trichomonas vaginalis: Pathogenesis, symbiont interactions, and host cell immune responses. Trends Parasitol 2018; 34: 683-693.

5. Mukanyangezi MF, Sengpiel V, Manzi O, Tobin G, Rulisa S, Bienvenu E, Giglio D. Screening for human papillomavirus, cervical cytological abnormalities and associated risk factors in HIV-positive and HIV-negative women in Rwanda. HIV Med 2018; 19: 152-166.

6. Rendón-Maldonado J, Espinosa-Cantellano M, Soler C, Torres JV, Martínez-Palomo A. Trichomonas vaginalis: in vitro attachment and internalization of HIV-1 and HIV-1-infected lymphocytes. J Eukaryot Microbiol 2003; 50: 43-48.

7. Guenthner PC, Secor WE, Dezzutti CS. Trichomonas vaginalis-induced epithelial monolayer disruption and human immunodeficiency virus type 1 (HIV-1) replication: implications for the sexual transmission of HIV-1. Infect Immun 2005; 73: 41554160.

8. Garber GE, Sibau L, Ma R, Proctor EM, Shaw CE, Bowie WR. Cell culture compared with broth for detection of Trichomonas vaginalis. J Clin Microbiol 1987; 25: 1275-1279.

9. Kaydos-Daniels SC, Miller WC, Hoffman I, Banda T, Dzinyemba W, Martinson F, Cohen MS, Hobbs MM. Validation of a urinebased PCR-enzyme-linked immunosorbent assay for use in clinical research settings to detect Trichomonas vaginalis in men. J Clin Microbiol 2003; 41: 318-323.

10. Lee JJ, Moon HS, Lee TY, Hwang HS, Ahn MH, Ryu JS. PCR for diagnosis of male Trichomonas vaginalis infection with chronic prostatitis and urethritis. Korean J Parasitol 2012; 50: 157-159.

11. Dierkes C, Ehrenstein B, Siebig S, Linde HJ, Reischl U, Salzberger B. Clinical impact of a commercially available multiplex PCR system for rapid detection of pathogens in patients with presumed sepsis. BMC Infect Dis 2009; 9: 126.

12. Lee SJ, Park DC, Lee DS, Choe HS, Cho YH. Evaluation of Seeplex $^{\circledR}$ STD6 ACE Detection kit for the diagnosis of six bacterial sexually transmitted infections. J Infect Chemother 2012; 18: 494-500.

13. Madico G, Quinn TC, Rompalo A, McKee KT Jr, Gaydos CA. Diagnosis of Trichomonas vaginalis infection by PCR using vaginal swab samples. J Clin Microbiol 1998; 36: 3205-3210.

14. Paces J, Urbánková V, Urbánek P. Cloning and characterization of a repetitive DNA sequence specific for Trichomonas vaginalis. Mol Biochem Parasitol 1992; 54: 247-255.

15. Seo JH, Yang HW, Joo SY, Song SM, Lee YR, Ryu JS, Yoo ES, Lee WK, Kong HH, Lee SE, Lee WJ, Goo YK, Chung DI, Hong Y. Prevalence of Trichomonas vaginalis by PCR in men attending a primary care urology clinic in South Korea. Korean J Parasitol 
2014; 52: 551-555.

16. Strøm GE, Tellevik MG, Hanevik K, Langeland N, Blomberg B. Comparison of four methods for extracting DNA from dried blood on filter paper for PCR targeting the mitochondrial Plasmodium genome. Trans R Soc Trop Med Hyg 2014; 108: 488-494. 
